Available online on 15.04.2021 at http://jddtonline.info
Open Access to Pharmaceutical and Medical Research
unrestricted non-commercial use(CC By-NC), provided the original work is properly cited

Open Access Full Text Article

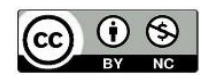

Review Paper

\title{
A Review on Chemical Constituents, Traditional Uses, Pharmacological Studies of Zanthoxylum armatum (Rutaceae)
}

\author{
Kapil Kumar Verma*, Bhopesh Kumar, Hans Raj, Akanksha Sharma \\ School of Pharmacy, Abhilashi University, Mandi-175028, Himachal Pradesh, India
}

\section{Article Info:

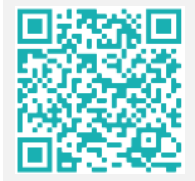 \\ Available online 15 April 202}

Cite this article as:

Verma KK, Kumar, K Raj H, Sharma A, A Review on Chemical Constituents, Traditional Uses,

Pharmacological Studies of Zanthoxylum armatum

(Rutaceae), Journal of Drug Delivery and

Therapeutics. 2021; 11(2-s):136-142

DOI: http://dx.doi.org/10.22270/jddt.v11i2-s. 4786

*Address for Correspondence:

Kapil Kumar Verma, School of Pharmacy, Abhilashi University, Mandi-175028, Himachal Pradesh, India

\begin{abstract}
Zanthoxylum armatum used as a medicine from ancient time for cure of various diseases such as toothache and problems related to tooth, asthma, used for gum bleeding, fever, dyspepsia, and tonics etc. Phytochemistry, pharmacological activities, diseases, traditional uses etc are explained in this review article.This article have information of the Z. armatum which may have Phytochemistry, pharmacological activities, diseases, traditional uses etc. Some latest info of Phytochemistry, pharmacological activities, diseases, traditional uses may show clearance in review. Different activities of various diseases known as antioxidants, antinociceptive, antifungal, antinflammtory, hepatoprotective, pesticides, anthelminitic, antiproliferative etc including chemical constituents like resins, 1alphaphellandrene, linalool, carbonyl compound, methyl n-nonylketone. Linalyl acetate, sesquiterpene, hydrocarbon, tricosaine, dictamine, fragarine, magnoflorine, skimmianine, xanthoplanine. It is expected that more investigation on plant can be done. This review article is helpful to get various important evidence regarding the plant Zanthoxylum armatum which will works as key point for the future investigation.
\end{abstract}

Keywords: Z.armatum, Phytochemistry, traditional uses, pharmacological activities.

\section{INTRODUCTION}

Medicinal property of plants are comes in highlight during ancient period. During Ancient times for rescue of diseases , people depend on nature. At that time they are not aware about medicinal nature of plants .Hence we can say that healing with medicinal plants as old as mankind itself. Human and his research for medicine from plants dates from the far past. Human struggles for many years to learned about therapeutic nature of many plants. Contemporary science has acknowledged their active action, and it has included in modern pharmacotherapy, known by Ancient Civilization and used throughout milennia.

Medicine from plants can derived from different plant parts i.e. leaves, roots, bark, fruits, seeds, flower. The different plant parts contain different ingredients within a plant. Hence, one part of the plant may be toxic while another part of the same plant harmless.Plants are an important source of medicine and plays an important role in world health. Many countries in the world that is two third of the world population depends on herbal medicine for primary health care. In India and other developing countries herbal or medicinal plants use to cure the therapeutic curative diseases.

Zanthoxylum armatum, is also known as winged prickly ash or timru. Is is belongs to the family Rutaceae. It is an aromatic, deciduous, spiny shrubs. Timru is an evergreen; small tree and height up to $6 \mathrm{~m}$.Leaves are around $20 \mathrm{~cm}$ long, aromatic and compound. Fruits are reddish in colour and around $5 \mathrm{~mm}$ in diameter ${ }^{1}$.Flowers are green to yellowish colour. Seeds are shiny and bitter. Fruits, seeds and bark and are used as cure of dyspepsia and fever. Fruits and seeds are useful for dental trouble thus many kind of dental paste and powder are made from it. It has many antiseptic properties. Mainly found in Himalayas Warmer valley 1000 to $2100 \mathrm{~m}$ from the sea level and moves from Jammu Kashmir to Assam.

Synonyms of Z. armatumare Z. planispinum, Timru, Timber, Toothache Tree, Winged prickly ash. Found in India, Meghalya, Mizoram and Manipur ${ }^{2}$. There are 11 species and genus of the $Z$. armatum thats mainly found as medicinal plants, $Z$. budrunga, Z. oxyphyllum, Z. ovalifolium, $Z$. acanthopodium, Z. planispinum, Z. armatum, Z. nitidium, $Z$. rhesta, $Z$. simulans, $Z$. avicennae and $Z$. limonella. Out of these, 4 species are $Z$. armatum $D C$., $Z$. acanthopodium $D C$., $Z$. oxyphyllum Edgew, and Z. budrunga are present in India. These species which may used as a medicinal plants have more effectiveness against the diseases and more curable without having any side effects ${ }^{3}$.

Z.armatum are used as a medicine from ancient time for cure of various diseases such as toothache and problems related to tooth, asthma used for gum bleeding, fever, dyspepsia, 
and tonics etc ${ }^{4,5}$.The fruit part of the plant may used to purify the water.Also used as insect repellent. The wood of this pant may be very heavier and strong then it is used for walking sticks. Z. armatum also gives and showed work against antioxidants ${ }^{7}$, antinociceptive, antifungal, 8 antinflammtory, hepatoprotectie ${ }^{9}$, pesticides, anthelmiitic, antiproliferative ${ }^{10} \mathrm{etc}$.

The phytochemical investigation shows the presence of volatile oil and resins.1-alphaphellandrene, linalool, carbonyl compound, methyl n-nonylketone. Linalyl acetate, sesquiterpene, hydrocarbon, tricosaine, dictamine, fragarine, magnoflorine, skimmianine, xanthoplanine ${ }^{11,12}$. Essential oils known as fennel, citronella, geranium, lavender and rosemary are used to be fragrance and in food and beverages ${ }^{13,14}$.

\section{COMMON NAMES}

Sanskrit: Tumbru, dhiva, ghndhalu

Hindi: Dharmar, tejphal, nepalidhaniya.

Bengali: Gaira, tambal

Oriya: Tundopoda

\section{TAXONOMICAL CLASSIFICATION}

Kingdom: Plantae

Class: Magnoliopsida

Order: Rutales

Family: Rutaceae

Genus: Zanthoxylum

Bionomial Name: Zanthoxylum armatum

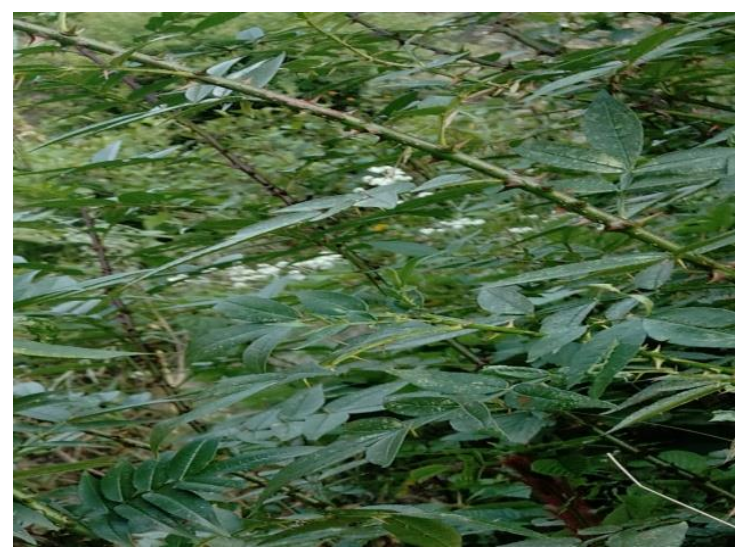

Figure 1: Plant of Z. armatum

\section{DISTRIBUTION}

Z. armatum belongs to family Rutaceae is a genus which is aromatic, prickly monoecious small tree or shrubs. Founds in Jammu Kashmir form altitude of 1000 to $1200 \mathrm{~mm}$ and in Orissa and Andhra Pradesh at $1200 \mathrm{~mm}$. Genus found in different place of the world like Eastern and Southeast Asia. In Southeast Asia India, Bangladesh, Bhutan, Vietnam, Cambodia, Thailand, Malaysia etc., Brazil, Argentina, Peurto Rico, Brazil, Africa, Ethiopa, Zimbabe ${ }^{14}$.This Genus of prickly, dioceous, monoecious tree distributed throughout the world. Around of 13 species of $Z$. armatum present in India. This plant may be found in warmer and tropical region. In India it is mainly found Assam, Manipur, Meghalya, Nagaland, Jammu Kashmir etc. The location for growth of these plant species may valleys, mountains, forestetc ${ }^{15}$.

\section{CULTIVATION}

Cultivated under moistening soil and well drained absorption of the soil in shadow or sunny environment. Flowers of this plant may found in old branches ${ }^{16}$. Unripped seeds may store. When seeds became ripped it may preserved into cold environment for 3 months ${ }^{17}$. Growth takes 6 months and a mature seeds found it may also takes 12 months more.After this seeds may obtain and pricked from the soil. This procedure may be performed when the seeds may grow enough and handling in easy to growth of the plant. Wood may cut when it is half ripped. Roots growth is to be $3 \mathrm{~cm}$ and cut down after this it may show good yield. Some of extra grass woods etc are prunning out then the plant sown on their permanent position and mature properly ${ }^{18}$.

\section{DESCRIPTION}

Tree are $6 \mathrm{~m}$ tall having armed branches and prickles flattened upto $2 \mathrm{~cm}$ long, barks are pale brownish in colour. Leaves are $23 \mathrm{~cm}$ long and trifoliolate, leaflets have 5 pairs, ovate and lanceolate, glandular. Flowers are green to yellowish colour having axilary panicles and foliclles are generally red in colour, Seeds found into fruit, shinning black in colour ${ }^{19}$. The male and female flowers occurs, the male flowers are yellow colours and the female flowers are 1to 3 carpelled. Fruits have purplish red colour and have around 4 mm diameter. Flowers having growth April to May and fruits grown August to November and the fruits may appears in tree all over the year ${ }^{20}$.

\section{USES}

Z. armatum mainly used in chronic problems that is skin disease, rheumatism, toothache, gum bleeding, cramps in legs, varicose veins, varicose ulcer, low blood pressure, fever and inflammation, fibrositis, lymphatic system, circulation etc $^{20}$. Fruits and seeds are usually used as a condiment and spice in momos, chowmien, biscuits, thupka, sweetened cakes etc. The fruit part of the plant may used to purify the water. Also used as insect repellent. The wood of this pant may be very heavier and strong then it is used for walking sticks. Z. armatum also contains essential oils and also known as a ornamental plant 21 . Used as a flavouring agent. The fruits may have aromatic fragrance which used in different drinks as a flavours. The species of the Z. armatum may give anticancer activity, antifungal, antinflammatory, antioxidants etc. It may have various phytochemicals which may gives effect against various diseases such as lignans, alkaloids, monoterepeniol, polyphenolic and flavonoid groups etc. Where mainly the phenolic and flavonoids gives antioxidant activity and anticancer activity ${ }^{22}$. Shoots of the Timru useful for the gums bleeding and the toothaches. The powder form of the plant may used for the cleaning teeths. The constipation and dysentery or stomachic the soups are used for ailments. The pharmaceutical companies may start the timur production by using the non-timber forest product(NTPF) by manufacturing the different types of pastes by using the timber. Also considered for religious significance and for magical power ${ }^{1}$.

\section{CHEMICALCOMPOSITION:}

Plant Zanthoxylum armatum contains alkaloids such as gfagarine, b-fagarine, magnoflorine, nitidine, chelerythrine, tambatarine. It also contains linalool, beta-sitosterol, tamblin, tambulatin, aramatamide, lignans, asarinin and fragesin. Bark of plant contains yellow crystelline compounds named as berberine ${ }^{23}$. Many chemical studies are done which introduced the isolation of further two new phenolic compounds 3-3',4'-dimethoxyflavone-5- $\beta$-d- 
xylopyranoside along with the five known compounds, 1methoxy- 1,6,3-anthraquinone, 1-hydroxy- 6,13-anthra quinone, 2-hydroxybenzoic acid, 2-hydroxy-4-methoxy benzoic acid and stigmasta-5-en-3 $\beta$-deglucopyranoside, on the basis of spectral data and chemical analyses ${ }^{24}$.Two new phenolic glycoside, 2-methoxy-4-hydroxylphenyl-1-0- $\alpha$-Lrhamnopyranosyl- $\left(1^{\prime \prime} \rightarrow 6^{\prime}\right)-\beta-$ D- glucopyranoside and threo-3-methoxy-5-hydroxy-phenylpropanetriol-8-0- $\beta$-Dglucopyranoside were isolated from the stems of Zanthoxylum armatum 25

Zanthoxylum armatum also have linalool and limonene which are the constituent of essential oil. From the bark of this plant armatamide which is a amide is identified. Seed part of this plant consist hydroxylicenolic acid and other volatile compound 26 . Stem and root part of plant consists beta-amyrin, beta-sitosterol, lasarinin and L-plananin and zanthobungeneanine. Mythylcinnamate, limonine, carvone, linalool, palmitic acid, p-cymene are some other compounds present in Zanthoxylum armatum ${ }^{27}$. A new amide is identified named as armatamide which have two lignansfargesin and asarinin. Along with it contains alpha and beta amyrin, lupeol and beta-D-glycoside are identified $^{28}$. In DPPH free radical assay with IC 50 values of 323 and $114 \mathrm{mM}$ respectively these compounds showed weak scavenging activity ${ }^{26}$.

It contains alkaloids, flavanoids, saponin, steroids, terpenes, phenols, carbohydrates, proteins, amino-acid and essesntial oil including other constituents like arginine, aspartic and glutamic acid, glycine, histidine, threonine, tyrosineetc ${ }^{29}$. Bark part of the plant mainly contains lignans as fargesin, sesamin, eoieudesmin, eudesmin including the neutral lactones as pulvatide, 8-hydroxyl, dictamine, magnofluorine, $y$-fagarine, xanthoplanine, triterpenoids as $\beta$-amyrin and amyrenone. And the fruit part of the plant Zanthoxylum armatum contains the flavanoids as tambulin and tambulol; linalool, essential oil containing citral, limonene, sabinene, linalyl acetate, geraniol, methyl cinnamate, cineole, monoterpentriols as 3,7-dimethyl-1-octane - 3,6,7 -triol, trans cinnamic acid, nevadensin, umbelliferone, $\beta$-sitosterol and its glucoside ${ }^{30}$.

On the other side the aerial part of the plant consists pinoresinol diethyl ether and sitosterol. The oil obtained from the Zanthoxylum armatum contains linalyl acetate, phenols, methyl-n-nonyl ketone, sesquiterpenes hydrocarbon, tricosane, citronellal, 1,8- lineole and limonene 31 . With this the wood part of the plant consists xanthoplanine and magnoflurine. Other than this Zanthoxylum armatum are good source of volatile oil in which linolool is a main active constituents, lignan and limonene and are responsible for many biological activity which possess therapeutic effects such as anti-fungal, hepatoprotective, antilarvicidal and allelopathicproperties ${ }^{32}$. Phytochemical investigations of plant give knowledge that plant Zanthoxylum armatum yield three other chemical constituents 1-linoleo-2,3-dione, alpha-amyrin acetate and armatonaphthylarabinoside which are elucidated by using the chromatography technique and spectroscopy. Among these isolated chemical constituents armatonaphthyl arabinose is a new naphthylglycoside ${ }^{33}$. Zanthoxylum armatum is good source of essential oil which consists good amount of chemical constituents and possess many therapeutic activity. These chemical contituents are linalool, myrcene, cinnamate, tridecan-2-one, limonene, undecan-2one, alpha-Bergamotene ${ }^{34}$. Other compound isolated from the essential oil is Zanthoxylum armatum are beta-linalool, alpha-limonene diepoxide, alpha-pinene, beta-myrcene and lastly D limonene 35 .

Zanthoxylum armatum are also have terepenoids manly consisting monoterpenes including p-meth-1-en-8-ol $(2.47 \%)$, Geraniol acetate (1.32\%), cisbeta-Ocimene $(1.29 \%)$, Sabinene $(1.24 \%)$ and p-meth-1-en-8-ol, acetate $(1.05 \%)$ and sesqueterpenes i.e. Carryophyline $(1.32 \%)$ and Germacrene- D $(1.01 \%)^{36}$. In DPPH free radical assay with $\mathrm{IC}_{50}$ values of 323 and $114 \mathrm{mM}$ respectively these compounds showed good scavenging activity. And thus this palnt is also responsible for the anti-oxidant activity. Monoterpenes like linalool and limonene are the major constituents of the essential oil as Zanthoxylum armatum is manly consist essential oil[28]. Crystal of white colour is obtained from the hexane and acetate fraction from the methanolic extract of the plant and white crystals are also obtained from the hexane ethyl acetate fraction. Zanthoxylum aramtum also yields lignin, amides, lignin ${ }^{37}$. It is clear that plant Zanthoxylum armatum contains important active components such as alkaloids, coumarin, lignin, fatty acid glycosides, benzenoids, amino acids, phenols and flavonoids ${ }^{38,39}$. So we can say that this plant having many biological active compounds which are responsible for various pharmacological activities. And many more derivatives are found in the research ${ }^{40}$.

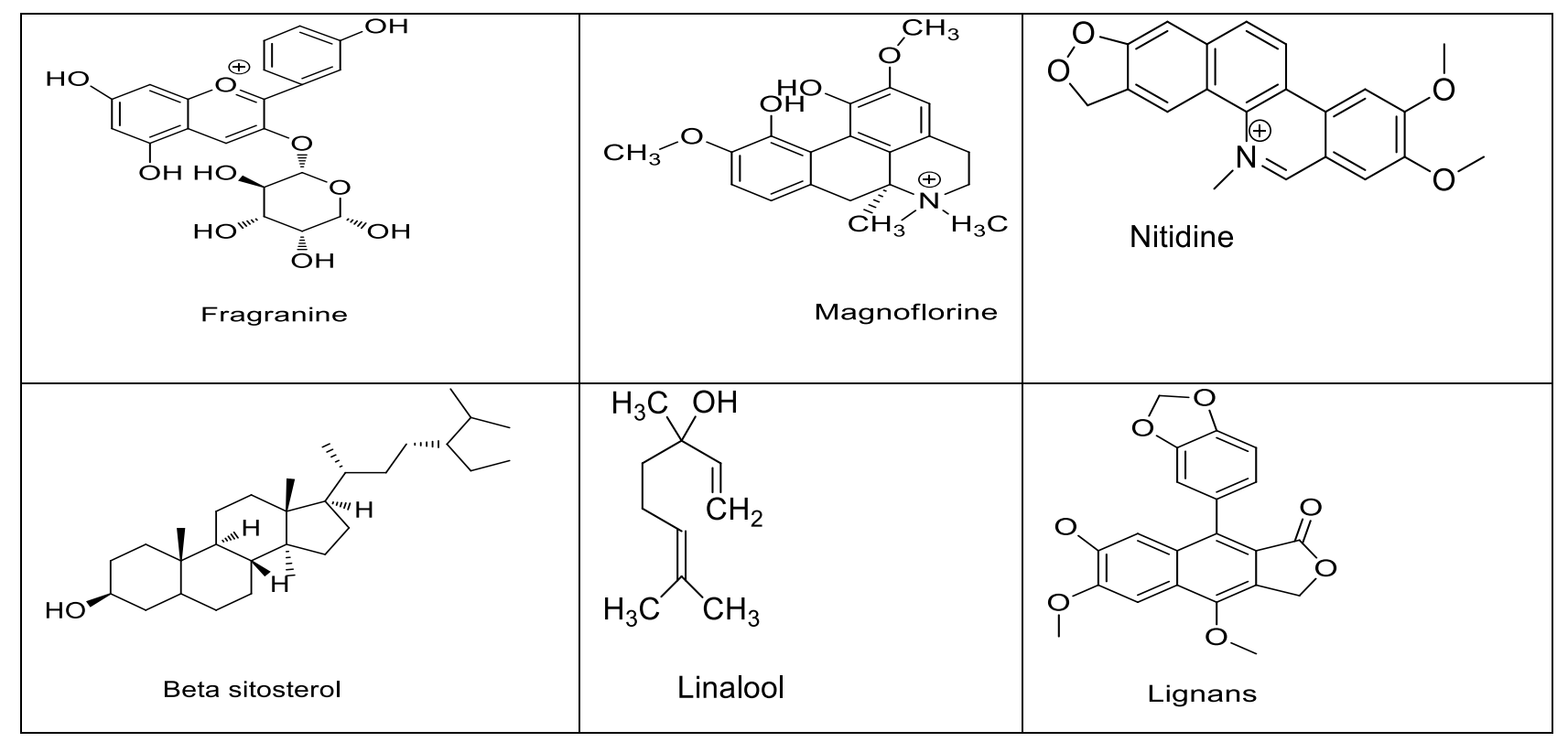




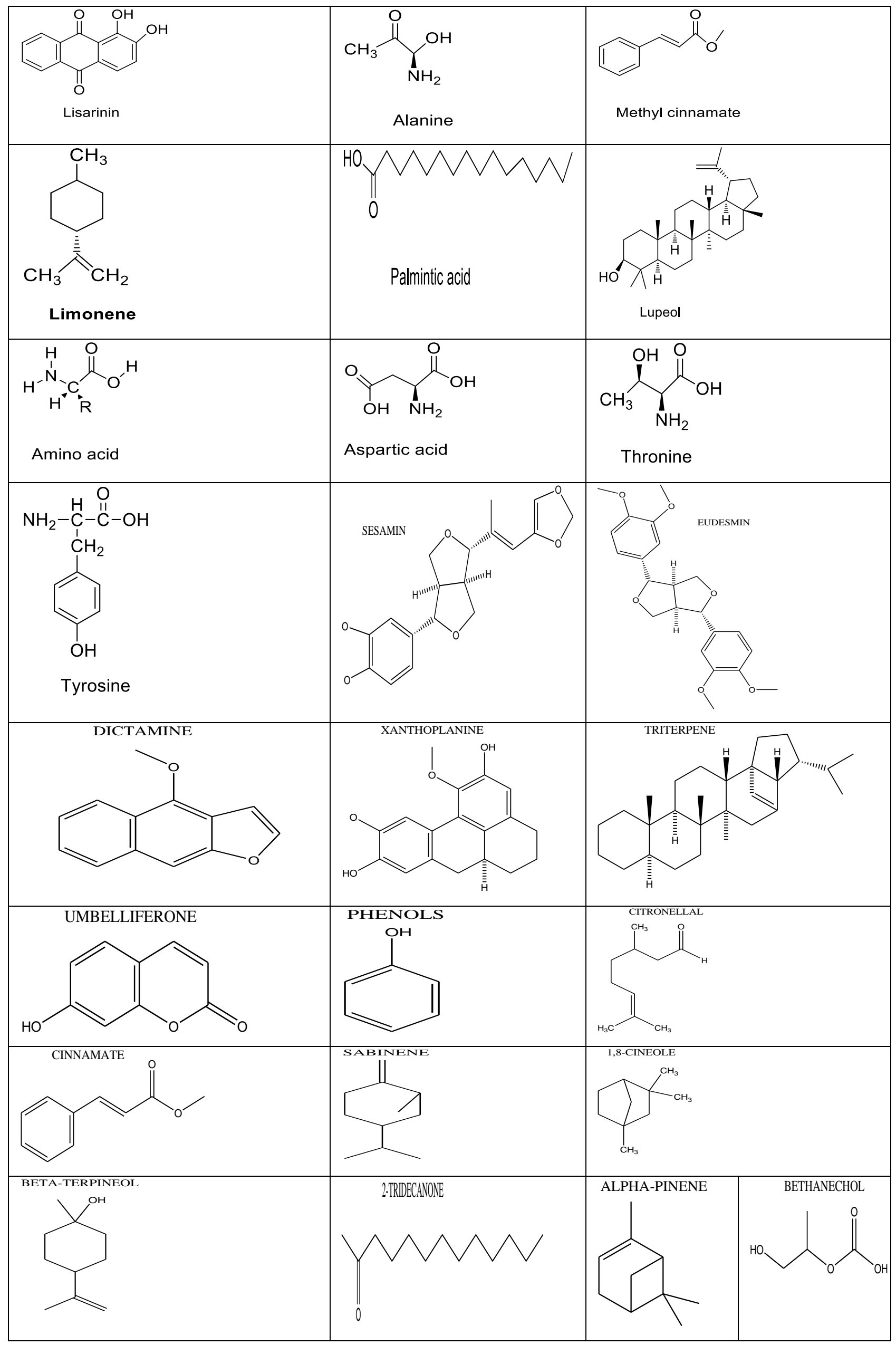




\section{PHARMACOLOGICAL ACTIVITY:}

Hepatoprotective Activity : Research investigate that plant Zanthoxylum armatum exhibits hepatoprotective activity with its ethanolic extract against the carbon-tetrachloride which damage the liver and it helps to normalizing the increase the level of hepatic enzymes. It also helps to manage the hepatocytes protects against the membrane fragility and decrease the marker enzyme leakage. And thus reported that this plant is helpful to protect the plasma membrane of the hepatocytes ${ }^{41}$.

Anti-diabetic activity: Previous studies gives knowledge about that this plant show good result in diabetic activity. It shows the anti-diabetic activity against the streptozotocin induced in diabetic rats. Glibenclamide was used as standard reference drug. Oral medication is carried out for 21 days which result in the significant reduction in blood glucose level hence helps in the reduction of the triglycerides, LDL and VLDL. And show the anti-diabetic activity ${ }^{42}$.

Anti-depressant activity: Various researchers identified that this plant also possess good anti-depressant activity. Depressant activity is of the component present in this plant is checked out by bioassay guided fraction. Mostly the hexane extract show good potency of anti-depressant activity. Molecular and biochemical studies give significant result that the seed part of the plant zanthoxylumarmatum show the anti-depressant activity ${ }^{43}$.

Memory enhancing property: Zanthoxylum armatum was not studied for its neurological property so far. Previously it was used for tooth-ache. Then for the first time researcher conduct the detail study of memory enhancer by use of various hydroalcohlic extract. So it comes in result that plant Zanthoxylum armatum is one of the good memory enhancer 44 .

Cytotoxicity: Different studies illustrates that plant show result in cytotoxicity and in anti-oxidant potential. In research ethyl acetate extract of stem show good result in cytotoxicity. Cytotoxicity of ethyl acetate was studied on the different cancerous cells ${ }^{45}$. Mainly this extract of the plant show good result on the pancreatic and lungs cell lines. The plant extract of the Zanthoxylum armatum are also useful to increase the efficiency of the chemotherapeutic drugs such as mitomycin C, cisplatin and camptothecin ${ }^{46}$.

Anti-Spasmodic Ativity- Result of research showed that Zanthoxylum armatum exhibits anti-spasmodic effect by the Ca antagonist mechanism which is a base of pharmacological activity and provides good result in cardiovascular, respiratory disorders ${ }^{47}$. Zanthoxylum armatum hexane extract give good anti-spasmodic effects. The entire samples are tested against smooth muscle induced from spontaneous and potassium chloride which is isolated from the rabbit jejinum $^{48.49}$.

Mosquito and insect repellent-Essential oil of plant Zanthoxylum armatum have insect or leech repellent activity. Research show that repellent property of $\mathrm{N} \mathrm{N}, \mathrm{N}$-diethyl phenyl acetamide (DEPA), N, N-diethyl-m-toluamide (DEET), 3-acetyl-2 (2,6-dimethyl-5-heptenyl) oxazolidine (citronyl), dimethyl phthalate (DMP) and N-benzoyl piperidine (NBP) were tested against leech. Result obtained from the research compared with its volatile oil and then evaluate its repellent activity ${ }^{50}$.

Anti nociceptic and anti-convulsant activity- Essential oil of plant Zanthoxylum armatum obtained from the steam distillation were evaluated against anti-convulsant, antitoxicity and toxicity. Zanthoxylum armatum relieve from the neurogenic pain and inflammation ${ }^{51}$.
Anti-proliferative Activity- Methanolic extract of plant Zanthoxylum armatum show anti-proliferative activity it works against the human keratinocytes. Studies suggest that this methanolic extract works with four different species of the plant Zanthoxylum armatum. Research suggests that the anti-proliferative is not due to the cytotoxic effect but they protect against radical induced damage model ${ }^{52}$.

Soothing effect on Skin- The lipophillic extract of the plant Zanthoxylum armatum with alcohal shows the soothing effect on skin and sensory inhibition from the sun bathing, insect bites, shaving depilation and chemical treatment ${ }^{53}$.

Some other effects- There are also some toxicological effects of the plant Zanthoxylum armatum. Extract, decoction, pastes like prepration shows some toxicities which is studied by many researchers. Research also suggests that the aquous extract of the Zanthoxylum armatum which are used in traditional herbs medicine remedy exerts their toxic potential by inducing the membrane damage of cellualr organs also show chromosomes clumps and nuclear DNA damage ${ }^{54}$.

Antinflammatory activities- ${ }^{55}$ The $Z$. armatum may have antioxidant properties, for this the stem bark extract has been used in Wistar rat by inhibiting the cyclooxygenase. Fruit extract of the plant also used for inhibition of carrageenan that may produce in wistar rats. It may have various constituents one of them is lignans which may show analgesic effect also ${ }^{56,57}$.

Antioxidative activities-58,59 Methanolic and Ethanolic fruit extract of plant shows in vitro activities in Wistar rats and due to presence of free radical scavanging it may shows the antioxidants activities against the Wistar rats.

Antimicrobial activities ${ }^{60}$ Activities may show the effect against microorganisms. Bacillus subtilis shows zone of inhibition and minimum bactericidal concentration. The oils composition may also shows the fungicidal activities against Alternaria brassicicola.

Larvicidal activities-It contain larvacidal activities against the Aedes aegypti, Anopheles stephensi, C. pipenes. 61

Piscicide activities-62Fruit part of the plant may show the effect against the piscicide activity in fish nursery management. Alcoholic extract found magnesium, sodium, potassium in various tissues of the air breathing catfish. Various studies may show the effect of Piscicide activity.

Hepatoprotective activities-63Ethanolic leaves extract may shows the effect in mice liver in which $\mathrm{CCL}_{4}$ shows hepatoprotective activities including inflammatory activity. The enzymatic also regulates by the bark extraction of the plants along with antioxidant enzymes from this it may used to give a positive effect against the hepatoprotective activity in mice. This study was performed in rats.6rats were divided into four groups and different doses of different doses were given to them. All doses were formed by gastric incubations for 7 days. On $8^{\text {th }}$ day CCl4 dose were administered to rats with liquid paraffin. The liver of rats may dissected and blood was taken from the cardiac and centrifuged. All this the hepatoprotective activity has been shown in a liver ${ }^{64}$.

Antitumor Activity- 65 Z. armatum also have anticancer activity. The fruits and leaves may show the anticancer effects by having a monoterpeneleupol which shows the therapeutic and chemoprotective effects.

Immunomodulation activities- ${ }^{66}$ Crude extract of the timber is used as gastrointestinal effect, cardiovascular, by showing concentration effect on the potassium and calcium. 
And also the effects against circulation, mucous membrane, and also shows effect on the fibrosis and rheumatism.

Cardiovascular Activity-66 Z. armatum may have antispasmolytic effect and arrythmic effect in crude extract. It may inhibit by calcium antagonistic mechanism which may used for Gastrointestinal effect, respiratory and cardiovascular disorders. Verapamil which is calcium channel blocker used for the cardiac diseases.

\section{CONCLUSION}

Herbal medicinal plant contributed highly in the allophathic and various traditional system of medicine. And provide ingredients for drug and which is helpful for the new drug discovery. Zanthoxylum armatum consists of many biological active components which are used in Indian system of medicines. The above study of Zanthoxylum armatum gives important information that it is a fast growing species and low population sizes. This review article highlights the botany, phyto-constituents and various pharmacological activities. Study suggests that plant Zanthoxylum armatum have many pharmacological active chemical constituents which are responsible for various disorders. Zanthoxylum armatum is one of that plant used in traditional system of medicines since long time. Different parts of plant show different activities. Recently there are many research are being done on plant Zanthoxylum armatum and from this various other derivatives are identified like from amide, lignane many derivatives are identified. And this plant is one of the most useable sources of essential oil. However, there may be still need of more investigation because this plant is rich source of various phyto-constituents and many more derivatives can be investigated further. It is expected that more investigation on plant can be done. This review article is helpful to get various important evidence regarding the plant Zanthoxylum armatum which will works as key point for the future investigation.

\section{REFERENCES}

1. Kala CP, Farooquee NA, Dhar U. Traditional Uses and Conservation of Timur (Zanthoxylum armatum DC.) through Social Institution in Uttaranchal Himalaya, India.Conserv, Soc. 2005; 3(1):224-230.

2. Gupta S, Bhaskar S, Andola HC. Altitudinal Variation in Essential Oil in Leaves of Zanthoxylum alatum Roxb. A High Value Aromatic Tree from Uttarakhand. J. Med. Plant Res. 2011; 5(3):348-351.

3. Samant SS, Dhar U, Palni LMS. Medicinal plants of Himalaya: diversity, distribution and potential values. Himavikas, Gyan Prakash, Nainital. 1998; 13:163-172.

4. Ramchandran R, Ali M.Chemical composition of fruit oil of Zanthoxylum armatum. Hamdard Med. 1996; 4:42-51.

5. Chopra RN. Glossary of Indian Medicinal Plants.1956; 1:417 423.

6. Guo T, Deng YX, Xie H, Yao CY, Cai CC, Pan SL. Antinociceptive and anti-inflammatory activities of ethyl acetate fraction from Zanthoxylum armatum in mice. Fitoterapia.2011; 51:338-347.

7. Sati SC, Sati MD, Raturi R, Badoni P. Anti-inflammatory and antioxidant activities of Zanthoxylum Armatum Stem Bark. GJRE.2011; 3:11-21.

8. Ramanujam SN, Ratha BK. Effect of alcohol extract of a natural piscicide. Fruits of Zanthoxylum armatum DC. on Mg2+- and $\mathrm{Na}+, \mathrm{K}+-$ ATPase activity in various tissues of a freshwater airbreathing fish. Heteropneustesfossilis.Agriculture.2008; 283:7782.

9. Mehta MB, Kharya MD, Shrivastva R, Verma KC. Antimicrobial and antihelmintic activities of the essential oil of Zanthoxylum alatum Roxb. India Perfum.1981; 25:19-21.

10. Baquar SR. Medicinal and poisonous plants of Pakistan. Printas: Karachi. 1989; 478.

11. Kapoor LD. Handbook of Ayurvedic medicinal plants. CRC Press: Boca Raton. 1990; 339-340.
12. Curtis CF, Lives JD, Baolib LU, Renz A. Natural and synthetic repellents, pp.75-92. In: Curtis CF, (ed.), Appropriate Technology in Vector Control. CRC, Boca Raton FL, Fradin MS. Mosquitoes and mosquito repellents: a clinician Õs guide; 1998: Ann. Intern. Med. 1990; 128: 931-940.

13. Brown M, Hebert AA. Insect repellents: an overview. J. Am. Acad. Dermatol. 1997; 36:243-249.

14. Ranawat LS, Bhatt J, Patel J. Hepatoprotective activity of ethanolic extracts of bark of Zanthoxylum armatum DC. in CCl4 induced hepatic damage in rats. J. Ethnopharmacol. 2010; 127: 777-780.

15. Vana PD. Agro-technique study carried out by Regional Station, National Bureau of Plant genetic Resources, Dist Niglat, Nainital, Uttarakhand, B- RRL, CSIR, Itanagar, Arunachal Pradesh, Teri Press. India, New Delhi. 2008; 231-234.

16. Larkcom J, Oriental Vegetables. Well written and very informative. 1971.

17. Dirr MA, Heuser MW. The Reference Manual of Woody Plant Propagation. A very detailed book on propagating trees. Not for the casual reader. 1987

18. Sheat WG. Propagation of Trees, Shrubs, Conifers. A bit dated but a good book on propagation techniques with specific details for a wide range of plants. 1948.

19. Kirtikar KR, Basu BD. Indian Medicinal Plants, Lalit Mohan Basu, 4, Leaders Road, Allahabad. 1975; 461.

20. Flowers of India, Retrieved. 2021.

21. EPPO Global Database. Zanthoxylum armatum(ZANAP) EPPO. 2021.

22. Zoolfa N, Singh S, Kumar D, Tandon SS. Characterization and evaluation of bioactive polyphenolic constituents form Zanthoxyllum armatum.A traditionally used plant. Biomedicine and pharmacotherapy.2017; 89:366-375.

23. Siddhanadham AS, Yejella R, Prava R. Isolation, characterization, biological evaluation of two new lignans from methanolic extract of bark of Zanthoxylum armatum. Int J Pharmacog Phytochem. 2017; 9(3):395-399.

24. Akhtar N, Ali M, Alam MS. Chemical constituents from the seeds of Zanthoxylum alatum. J Asian Nat Prod Res. 2008; 11(1):91-95.

25. Krishnamurthi A. The Wealth of India: Raw Materials -Vol. VIII. India, New Delhi, Publications and Information Directorate, Council of Scientific and Industrial Research.1996; 394

26. Guo T, Dai LP, Tang XF. Two new phenolic glycosides from the stem of Zanthoxylum armatum DC. Nat Prod Res. 2017; 31(20):2335-2340.

27. Kalia NK, Singh B, Sood RP. A new amide from Zanthoxylum armatum. J Nat Prod. 1999; 62(2):311-312.

28. Vashist H, Sharma RB, Sharma D, Upmanyu N. Pharmacological activities on Zanthoxylum armatum. A review: World J Pharm Pharm Sci. 2016; 5:408-423.

29. Singh TP, Singh OM. Phytochemical and Pharmacological profile of Zanthoxylum armatum DC. An overview. Indian J Nat Prod Res. 2011; 2(3):275-285.

30. Watson E. The Principal Articles of Chinese Commerce. Shanghai: Statistical Department of the Inspectorate General of Customs.2013; 2: 491.

31. Anonymous, Wealth of India, A Dictionary of Indian Raw Materials and Industrial Products, National Institute of Science Communication, CSIR, first supplement series (raw materials), New Delhi. 2004.

32. Agrawal SS, Swami MP. Doctoral Dissertation in Pharmacy, University of Delhi, India. 2004.

33. Jain N, Srivastava SK, Aggarwal KK, Ramesh S, Kumar S. Flavour Fragr. J. 2001; 16:408.

34. Guleria S, Tiku AK, Koul A,Gupta S, Singh G, Razdan VK. Antioxid ant and Antimicrobial Properties of the Essential Oil and Extracts of Zanthoxylum Alatum Grown in North-western Himalaya. Sci. World J. 2013; 1:9.

35. Barkatullah M,Muhammad N, Rehman I, Rehman MU, Khan A. Ch emical Composition and Biological Screening of Essential Oils of Zanthoxylum Armatum DC Leaves. J. Clin. Toxicol.2013; 3(5):1-6.

36. Shinwari Z, Watanabe T, Rehman M, Youshikawa T. A pictorial guide to Medicinal Plants of Pakistan. KUST Kohat, Pakistan. 2006.

37. Brijwal L, Pandey AS, Tamta S. An overview on Phytomedicinal approaches of Zanthoxylum armatum DC: An important magical medicinal plant. J Med Plant Res. 2013; 7(8):366-370. 
38. Ahmad A, Mishra IN, Gupta MM. Volatile Oil component from the seed Zanthoxylum armatum. J. Natural Product.1993; 56:456460.

39. Gilani SN, Khan A, Gilani AH. Pharmacological basis for the medicinal uses of Zanthoxylum armatum in gut, airways and cardiovascular disorder.Phyto Other Res. 2010; 54:553-558.

40. Kala CP, Farooquee, NA. Dhar U. Traditional uses and conservation of Timur Zanthoxylum armatum DC) through social institutions in Uttaranchal Himalaya, India. Conserv Soc. 2005; 3(1):224-230.

41. Verma N, Khosa, RL. Hepatoprotective activity of leaves of Z armatum DC in CCl4-induced hepatotoxicity in rats.Indian J BiochemBiophys. 2010; 47(2):124-127.

42. Karki H, Upadhayay K, Pal H. Antidiabetic potential of Zanthoxylum armatum bark extract on streptozotocininduced diabetic rats. Int J Green Pharm. 2014; 8(2):77-83.

43. Barua CC, Haloi P, Saikia B. Zanthoxyllumalatum abrogates lipopolysaccharides-induced depression-like behaviours in mice by modulating neuroinflammation and monoamine neurotransmitters in the hippocampus. Pharm Biol. 2018; 56(1):245-252.

44. Saikia B, Barua CC, Sarma J. Zanthoxyllumalatum ameliorates scopolamine-induced amnesia in rats: Behavioral, biochemical and molecular evidence. Indian J Pharmacol.2018; 50(1):30-38.

45. Barkatullah B, Ibrar M, Muhammad N. Evaluation of Zanthoxylum armatum DC for in-vitro and in-vivo pharmacological screening. African J Pharm Pharmacol. 2011; 5(14):1718-1723.

46. Barkatullah B, Ibrar M, Muhammad N. Chemical Composition and Biological Screening of Essential Oils of Zanthoxylum armatum DC Leaves. J ClinToxicol.2013; 3:1-6.

47. Saikia B, Barua CC, Haloi P. Anticholinergic, antihistaminic, and antiserotonergic activity of n-hexane extract of Zanthoxylum alatum seeds on isolated tissue preparations: An ex vivo study. Indian J Pharmacol. 2017; 49(1):42-48.

48. Hemming JM, Guarraci FA, Firth TA. Actions of histamine on muscle and ganglia of the guinea pig gallbladder. Am J Physiol Gastrointest Liver Physiol. 2010; 279(3):622-630.

49. Matsumoto T,Horiuchi M, Kamata K. Effects of Bidenspilosa L. var. radiata SCHERFF treated with enzyme on histamineinduced contraction of guinea pig ileum and on histamine release from mast cells. J Smooth Muscle Res. 2009; 45(2-3):7586.

50. Dube S, Kumar A, Tripathi SC. Antifungal and insect repellent activity of essential oil of Zanthoxylum armatum linn. Curr Sci.1961; 30:223-224.

51. Muhammad I, Naveed M, Barkatullah HK. Antinociceptive and anticonvulsant activities of essential oils of Zanthoxylum alatum. Phytopharmacol.2012; 3:191-198.
52. Kumar S, Muller K. Inhibition of keratinocyte growth by different Nepalese Zanthoxyllum species. Phytother Res. 1999; 13(3):214-217.

53. Guglielmini G, Crtoni A. Zanthoxylum armatum extract inhibits skin sensitivity. Cosmet Toilet. 2002; 117(7):47-54.

54. Kharshiing EV. Aqueous extracts of dried fruits of Zanthoxylum armatum DC (rutaceae) induce cellular and nuclear damage coupled with inhibition of mitotic activity in vivo. Am J plant Sci. 2012; 3(11):1646-1653.

55. Sati SC, Sati MD, Raturi R, Badoni PP. A New Flavonoidal Glycoside From stem bark of Zanthoxylum armatum. IJPI's J. Pharm. Herb.Form. 2011; 1(2):29-32.

56. Kaur, V., Kumar, T., Bora, S.K., Pharmacological evaluation of Zanthoxylum armatum root extract on analgesic and antiinflammatory activity. J. Pharm. Res. 2011; 4(8):25-61.

57. Guo, T., Denq, Y.X., Xie, H., Yao, C.Y., Cai, C.C., Pan, S.L., Wanq, Y.L., Antinociceptive and anti-inflammatory activities of ethyl acetate fraction from Zanthoxylum armatum in mice. Phytotherapy. 2010; 82(3):347-351.

58. Batool, F., Sabir, S.M., Rocha, J.B.T., Shah, A.H., Saify, Z.S., Ahmed, S.D., Evaluation of Antioxidant and free radical Scavenging activities of fruit extract from Zanthoxylum alatum: a commonly used Spice from Pakistan. Pak. J. Bot. 2010; 42(6):4299-4311.

59. Upadhyaya, K., Ashok, P.K., 2010. Concentration dependent antioxidant activity of Zanthoxylum armatum. J. Pharm. Res. 3(7):1581-1582

60. Parajuli, R.R., Tiwari, R.D., Chaudhary, R.P., Gupta, V.N., Fungitoxicity of the essential oils of some aromatic plants of manang against alternaria brassicicola. Sci. World. 2005; 3(3):39-43.

61. Yun, Z., Ying-Hui, P., Dong-Qin, Z., Fei-Fei, C., Qio-Hui, Q., Yi, H., Insecticidal activity of essential oil from Zanthoxylum armatum fructification against two mosquito species.Guihaia. 2010; 30(2):274-279.

62. Ramanujam and Ratha. Effect of alcohol extract of a natural piscicide-Fruits of Zanthoxylum armatum DC. on Mg2+- and $\mathrm{Na}+, \mathrm{K}+\mathrm{ATPase}$ activity in various tissues of a freshwater airbreathing fish, Heteropneustesfossilis. Aquaculture. 283(4):7782.

63. Verma, N., Khosa, R.L., Hepatoprotective activity of leaves of Z armatum DC in $\mathrm{CCl} 4$ induced hepatotoxicity in rats. Ind. J. Biochem.Biophys. 2010; 47:124-127.

64. Galigher AE, Kozloff E. Essential of Practical Microtechnique, 2nd Edition, Lea and Febiger, Philadelphia. 1971; 77.

65. Barkatullah U, Muhammad I, Muhammad N. Evaluation of Zanthoxylum armatum DC for in-vitro and in-vivo pharmacological screening. Afr. J. Pharm. Pharmacol. 2011; 5(14):1718-1723.

66. Gilani SN, Khan A, GilaniAH.Pharmacological basis for the medicinal use of Zanthoxylum armatum in gut, airways, and cardiovascular disorders.Phytother Res. 2010; 24(4):553-558. 